University of Nebraska - Lincoln

DigitalCommons@University of Nebraska - Lincoln

2020

Age discrimination and academic labor markets

Sam Allgood

Follow this and additional works at: https://digitalcommons.unl.edu/econfacpub

Part of the Education Economics Commons, Higher Education Administration Commons, Labor Economics Commons, and the Labor Relations Commons

This Article is brought to you for free and open access by the Economics Department at DigitalCommons@University of Nebraska - Lincoln. It has been accepted for inclusion in Economics Department Faculty Publications by an authorized administrator of DigitalCommons@University of Nebraska - Lincoln. 


\title{
Age discrimination and academic labor markets
}

\author{
Sam Allgood \\ University of Nebraska-Lincoln, \\ 525V CoB, Lincoln, NE 68588-0489, United States \\ E-mail: sallgood@unl.edu
}

\begin{abstract}
In a sample of Canadian Ph.D.'s, Warman and Worswick (2010) report that fortytwo percent obtained their degree at thirty-four years of age or older. One implication is that those starting their academic career vary in age. As a result, academic labor markets provide a somewhat unique way to investigate the outcomes of workers of different age with similar work experience. This study uses a national sample of over 9,00o faculty to look at the relationship between age at the time a person earns their degree and income. Older individuals are less likely to attend graduate programs in Carnegie Research I institutions, and they are less likely to find employment at a Research I institution. Males are less likely to obtain employment at Carnegie research or doctoral granting institutions even if they attended a graduate program in a Research I institutions. Regression analysis reveals a negative relationship between age at time of degree and earnings. The age penalty is largest for those with the title of professor working at Carnegie research/doctoral institutions. The size of the age penalty for females is less dependent on this distinction. Lastly, the age penalty is evident at the start careers as older faculty are found to learn less in the first three years of obtaining their degree.
\end{abstract}

Keywords: Academic labor markets, Age discrimination

Published in Journal of Economic Behavior and Organization 169 (2020) 70-78

DOI: 10.1016/j.jebo.2019.10.024

Copyright (C)2019 Elsevier B.V. Used by permission.

Submitted 4 June 2018; revised 25 October 2019; accepted 31 October 2019; published 27

November 2019. 


\section{Introduction}

Krause et al. (2012) find evidence, using anonymous job applications, that the likelihood of new Ph.D. economists obtaining a job interview is decreasing in age for those about thirty-two years of age. This is consistent with results for general labor markets that find diminishing opportunities for older workers (Carlsson and Eriksson, 2019; Rutledge et al., 2017 ; Farber et al., 2017). A limited set of job opportunities will manifest itself in different labor market outcomes, such as employment and income.

Neumark et al. (2019) identify seven reasons why firms engage in statistical discrimination, and even though academic labor markets differ from general labor markets, some of these reasons are still relevant. For example, Neumark et al. note that hiring firms might fear that older workers have diminished capability. The hiring of tenure track faculty is intended to be a long-term commitment where the institution invests heavily in new faculty with expectations of payoff later in the form of notable publication and reputation. Given evidence in economics that publications in leading journals decline rapidly with age (Oster and Hamermesh, 1998), institutions may be less interested in hiring older workers if it is believed they will be less productive.

Academic labor markets offer at least one advantage when looking at how age is related to labor market outcomes. Neumark et al. (2019) emphasize that experience is a difficult attributes to hold constant in audit studies of age discrimination because assigning workers of different ages the same work experience does not truly hold all else constant. Age can differ for academics with similar work experience because some individuals obtain their Ph.D. immediately after completing their undergraduate degree and others have gaps between the end of undergraduate school and the start of graduate school. A twenty eight-year-old new Ph.D. and a forty five-year old new Ph.D. may compete for the same assistant professor position and have identical academic experience. However, a fifty-year-old professor with twenty years of experience is unlikely to compete for the same academic job with a twenty eight-year-old new Ph.D. The labor market may place a positive or negative value on pre-graduate school experience. In addition, a statistical relationship between age at time of 
degree and income may reflect choices or it may reflect differences in opportunities. ${ }^{1}$

This paper uses a sample of over nine thousand faculty in a array of fields of study constructed from the National Survey of Postsecondary Faculty to identify a number of relationships between age and outcomes for faculty. The analysis uses a combination of survey and administrative data, which make it impossible to identify the mechanisms generating the relationships, but the results are informative. The analysis begins by describing the transition from graduate school to employment by restricting the sample to those within three years of obtaining their Ph.D. Those thirty-five and older at the time of their degree are thirteen percentage points less likely to obtain their degree from a Carnegie Research I Institution, and this result holds for males and females. This gap carries over into job placement as those older at time of degree are less likely to obtain employment at a research or doctoral institution. In contrast, Stock and Siegfried (2015) look at only economists and they find that age at time of degree does not predict entering what they define as a Tier 1 or Tier 2 graduate program.

Differences in earnings are analyzed using OLS to estimate the relationship between age at degree and earnings. Using the full sample, the estimates show that those older when they obtain their degree earn less, and this is true of both male and female faculty. The "age penalty" is larger for males, about $\$ 15,500$, than for females, about $\$ 10,100$. Male faculty with the title of professor face a substantial age penalty at research/doctoral institutions, and the penalty is larger than that faced by male professors at other institutions, such as liberal arts schools. The age penalty for female faculty with the title of professor does not depend on the Carnegie classification of the institution. At institutions that are not research/doctoral, there is less evidence for an age penalty, regardless of type of position or gender.

It is possible that the relationship between age and income reflects realized productivity. To eliminate this concern, the next set of regressions again restricts the sample to those within three years

1 This may be the "secret" that faculty know but do not discuss. As Tyler Cowen said in an interview "he was much older than a typical assistant professor would be. And of course, we don't practice age discrimination, and neither does anyone else, but ..." (Ellipsis is in the original). (https://medium.com/conversations- with-tyler/patrick-collison- stripe-podcast-tyler-cowen-books-3e43cfe42d10 ). 
of obtaining their degree. The estimates reveal a sizeable penalty for those that are older when obtaining their degree. The analysis finds that the age penalty for male professors is three times larger at research/doctoral institutions than for male professors at other institutions. Female professors also face an age-penalty, but it does not differ across types of institutions. In addition, there is no age-penalty for faculty with a title other than professor.

\section{Sample and data description}

Data is taken from the 2004 National Survey of Postsecondary Faculty (NSOPF). Over 26,0oo faculty completed the survey. Those completing the survey held a variety of different academic positions and they were employed at all types of post- secondary institutions. The individual data are also merged with data about the institutions at which the faculty member works and the institution at which the faculty member obtained their degree. ${ }^{2}$

The sample is restricted to only those with a doctorate or a first professional degree, and those with full-time employment at the primary institution. This includes dropping faculty stating that they have full time employment somewhere besides their primary institution of employment. ${ }^{3}$ Individuals with disabilities are also excluded from the sample.

The NSOPF includes faculty from almost every field-of-study (FOS) one can find at a modern academic institution. How- ever, fields such as culinary services and construction trades are non-traditional academic fields. The concern is that labor markets in these non-traditional fields operate differently so that the factors determining employment and salary are also different. Consequently, they are excluded from the analysis. The FOS that remain are: business, arts (visual and performing), biological sciences, communication, computer, education, engineering, English, language, health science, math, philosophy, physical sciences, psychology, and the social sciences (which includes economics).

2 All information about the survey and the sampling methods can be found at https://nces. ed.gov/surveys/nsopf/.

3 The primary institution of employment is the institution at which the faculty member was surveyed. 
There are a number of reasons why students have a gap between their undergraduate and graduate education. Employment is one reason, and it is possible that this employment is at a post-secondary institution. A person without a doctoral degree that is hired to teach at a college might return to school and obtain a doctorate as a condition of maintaining employment or for promotion. Such individuals will be older upon obtaining their degree but they will not enter the labor market. Fig. 1 shows a truncated version of a cumulative probability distribution with the $\mathrm{x}$-axis measuring age at time of highest degree minus age when starting current job. For example, a new faculty member that does not finish their degree until a year after they are hired would measure -1 on the x-axis. To help describe the data, the oldest quarter of the sample at the time they obtain their Ph.D. are designated mature (35 or older). The rest of the sample are called traditional. This ad hoc dichotomy is used in this section to describe the sample, but the continuous variable age at time of highest degree is used in the regression analysis that follows.

Mature employees are more likely to have started their current position before obtaining their degree. For example, fifteen percent of mature faculty held their job at least five years prior to obtaining their doctorate. This compares to about one percent of traditional faculty. Not surprisingly, there is a sharp rise at about one year prior to obtaining the degree. At this point, the two curves follow a fairly parallel path.

To study the impact of age at time of degree on labor market outcomes, it is necessary for a person with a newly obtained Ph.D. to go on the labor market. However, it is not uncommon for a graduate student to be hired if they have completed all degree requirements and they are deemed sufficiently far enough along on their dissertation. To allow for the hiring of ABDs (all-but-dissertation), but to exclude those not entering the job market upon completing their degree, faculty members holding their current position for more than one year prior to obtaining their degree are excluded from the sample. Allowing one-year ABDs is somewhat arbitrary, but not completing the degree in a timely fashion is likely to impact salary, and this would confound the results. ${ }^{4}$

4 The regression analysis found in the next section was re-estimated allowing for two-year ABDs, and the results were not altered. 


\section{Cumulative Probability}

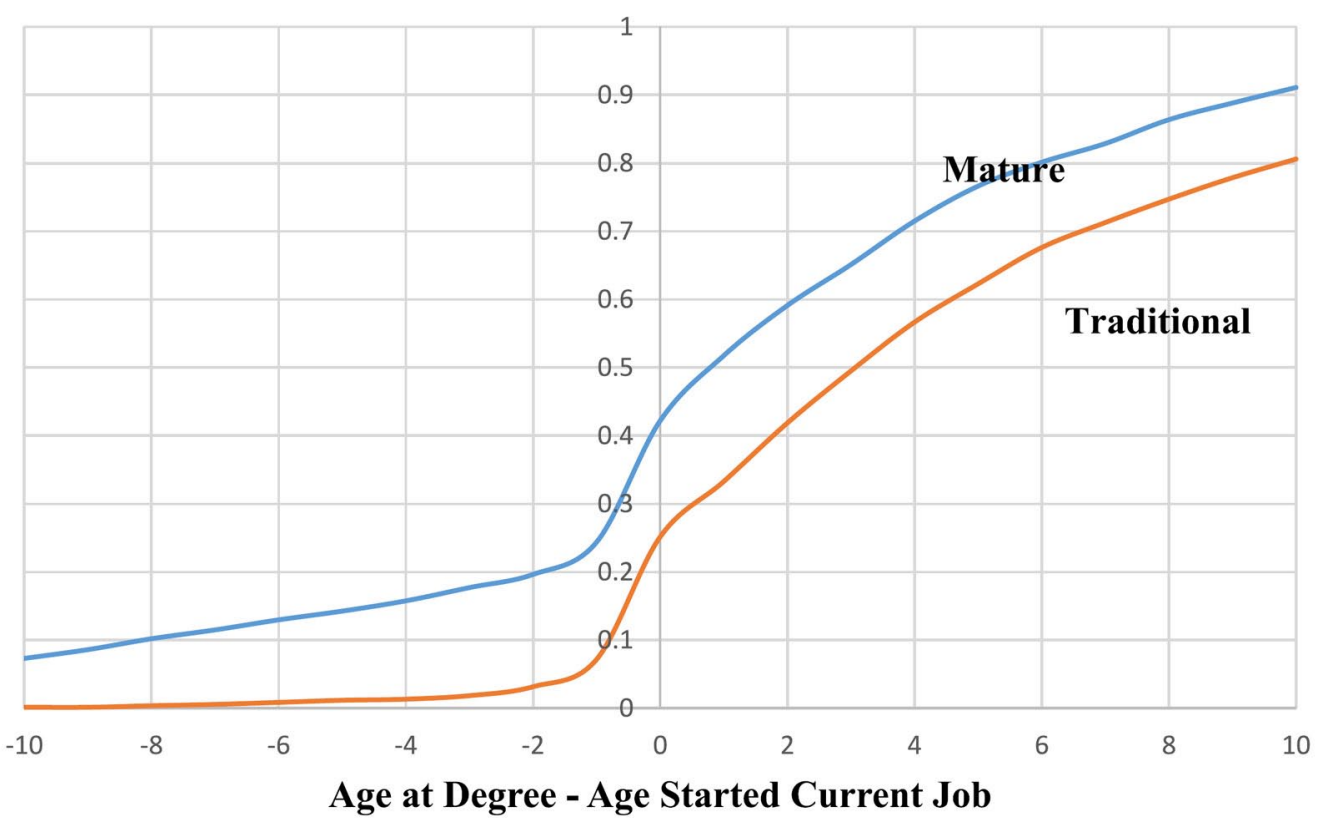

Figure 1. Cumulative probability of years in job at time of degree.

The hiring of new Ph.D.'s is often about expectations because there is no productivity to observe. To investigate if a bias against older new Ph.D.'s exists at the beginning of their careers, a sub-sample is analyzed that contains only those obtaining their degree within three years of the administration of the survey. The full sample has $9350 \mathrm{ob}-$ servations and the subsample of new faculty has 1090 observations. ${ }^{5}$

Fig. 2 is the percent of the sample obtaining their highest degree at a given age. Monks and Robinson (2000) document differences in academic salaries for males and females. As a result, the analysis is performed separately for the two groups. The data is separated for males and females. The shape of the two curves is very similar, but the curve for females peaks at a lower level than that of males. Late 20's and early 30's is the most likely time to obtain a degree, regardless of sex, but a larger fraction of males obtain their degree during these ages. For example, eighty percent of males obtained their degree by age thirty-five whereas this is only true for seventy percent of females.

5 All calculations use survey weights provided with the data set and survey commands in Stata. However, sample sizes are unweighted, and all un-weighted numbers are rounded to the nearest tenth. 


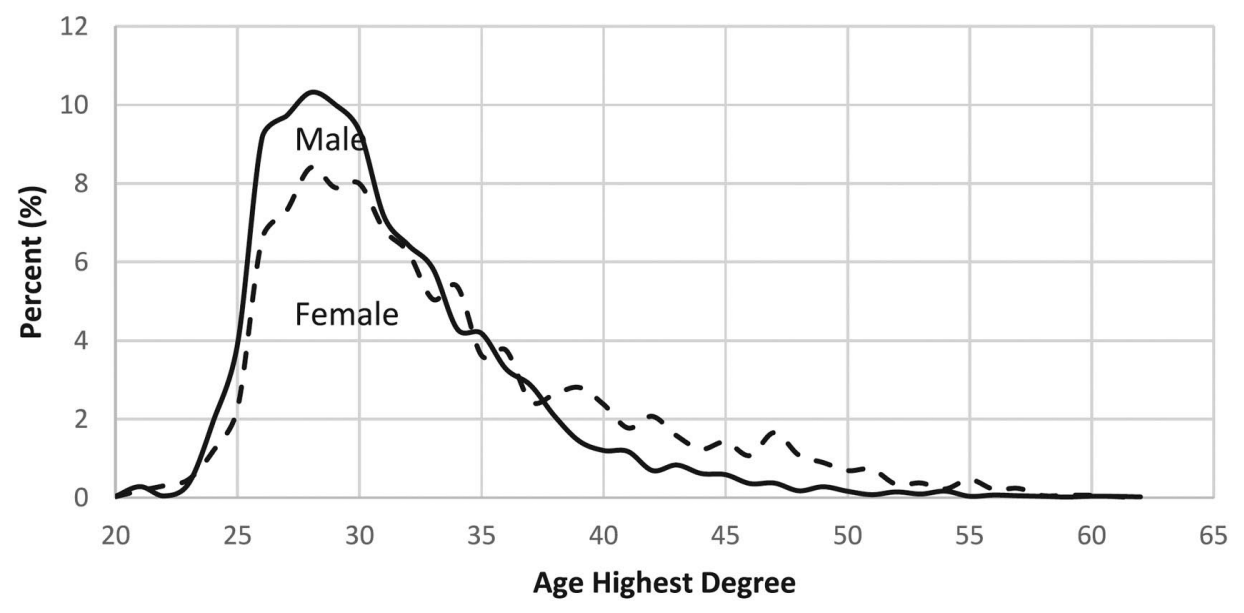

Figure 2. Age at time of degree.

Table 1 displays descriptive statistics for the full sample and the sample is broken-down by traditional and mature. Standard deviations are reported in parenthesis for continuous variables. Mature faculty are more likely than traditional faculty to be female and more likely black. Marital status varies with age in an expected manner, as does the number of children. Females have fewer children and are more likely to be born in the U.S.

Mature faculty are about eleven years older than traditional faculty upon obtaining their highest degree. This sample is younger than the sample of Canadian Ph.D.s studied by Warman and Worswick (2010) who report that forty-two percent of their sample got their Ph.D. at thirty-four or older. The data does not make it possible to identify a complete work history, so experience is years since obtaining degree. Using the Carnegie classification, a dummy variable is created that equals one if the person is employed at an institution with a research or doctoral classification (R/D). The criteria for being classified as research and doctoral are largely based on federal research funding and the number of doctorates granted. Carnegie classification is used as a proxy for the institutions emphasis on research. ${ }^{6}$ Traditional faculty are 20 percentage points more likely to be employed at a R/D institutions. Traditional males are more likely than traditional females to be employed at a R/D institution but no such gender difference arises for mature faculty.

6 For a definition of the Carnegie classifications see The Carnegie Classification of Institutions of Higher Education 2000 edition (http://carnegieclassifications.iu.edu/downloads/2000 edition data printable.pdf ). 
Table 1 Descriptive statistics.

\begin{tabular}{|c|c|c|c|c|c|c|c|}
\hline \multirow[t]{2}{*}{ Variable } & \multicolumn{3}{|c|}{ Full Sample } & \multicolumn{2}{|c|}{ Male } & \multicolumn{2}{|c|}{ Female } \\
\hline & All & Trad. & Mature & Trad. & Mature & Trad. & Mature \\
\hline Male & 0.691 & $0.727^{a}$ & 0.582 & & & & \\
\hline White & 0.826 & $0.834^{b}$ & 0.804 & 0.842 & 0.768 & 0.813 & 0.854 \\
\hline Black & 0.049 & $0.039^{a}$ & 0.080 & 0.031 & 0.077 & 0.060 & 0.086 \\
\hline Asian & 0.130 & 0.133 & 0.119 & 0.133 & 0.158 & 0.132 & 0.065 \\
\hline Single & 0.110 & 0.110 & 0.108 & 0.085 & 0.087 & 0.179 & 0.136 \\
\hline Married/Live Together & 0.041 & 0.040 & 0.044 & 0.031 & 0.031 & 0.065 & 0.061 \\
\hline Sep/Div/Wid & 0.089 & $0.077^{a}$ & 0.122 & 0.063 & 0.075 & 0.115 & 0.188 \\
\hline Children & $\begin{array}{c}1.008 \\
(1.259)\end{array}$ & $\begin{array}{c}1.051^{\mathrm{a}} \\
(1.249)\end{array}$ & $\begin{array}{c}0.878 \\
(1.278)\end{array}$ & $\begin{array}{r}1.115 \\
(1.115\end{array}$ & $\begin{array}{c}1.075 \\
(1.312)\end{array}$ & $\begin{array}{c}0.881 \\
(1.208)\end{array}$ & $\begin{array}{r}0.604 \\
(1.131)\end{array}$ \\
\hline Born US & 0.731 & 0.728 & 0.739 & 0.718 & 0.681 & 0.755 & 0.819 \\
\hline Age Highest Degree & $\begin{array}{l}31.886 \\
(6.536\end{array}$ & $\begin{array}{c}29.093^{a} \\
(2.950)\end{array}$ & $\begin{array}{r}40.236 \\
(5.911)\end{array}$ & $\begin{array}{c}28.996 \\
(2.875)\end{array}$ & $\begin{array}{c}39.259 \\
(5.167)\end{array}$ & $\begin{array}{l}29.35 \\
(3.131)\end{array}$ & $\begin{array}{l}41.596 \\
(6.592)\end{array}$ \\
\hline Experience & $\begin{array}{c}16.337 \\
(11.712)\end{array}$ & $\begin{array}{l}18.022^{a} \\
(11.872)\end{array}$ & $\begin{array}{l}11.299 \\
(9.018)\end{array}$ & $\begin{array}{c}19.440 \\
(11.572)\end{array}$ & $\begin{array}{l}12.397 \\
(9.326)\end{array}$ & $\begin{array}{c}14.239 \\
(11.068)\end{array}$ & $\begin{array}{c}9.770 \\
(8.056)\end{array}$ \\
\hline $\mathrm{ABD}$ & 0.003 & 0.002 & 0.006 & 0.002 & 0.003 & 0.001 & 0.01 \\
\hline Employer Is R/D & 0.570 & $0.620^{a}$ & 0.422 & 0.648 & 0.424 & 0.545 & 0.419 \\
\hline Professor & 0.897 & $0.903^{a}$ & 0.876 & 0.917 & 0.888 & 0.867 & 0.859 \\
\hline Lecturer/Instructor & 0.047 & $0.043^{b}$ & 0.057 & 0.034 & 0.048 & 0.066 & 0.068 \\
\hline Other Rank or NA & 0.057 & $0.053^{b}$ & 0.068 & 0.048 & 0.064 & 0.067 & 0.073 \\
\hline Administrator & 0.106 & 0.103 & 0.115 & 0.104 & 0.100 & 0.100 & 0.136 \\
\hline Tenure/Tenure Track & 0.772 & 0.777 & 0.758 & 0.802 & 0.781 & 0.710 & 0.727 \\
\hline Number of Classes & $\begin{array}{c}2.068 \\
(1.684)\end{array}$ & $\begin{array}{c}1.919^{\mathrm{a}} \\
(1.640)\end{array}$ & $\begin{array}{c}2.512 \\
(1.720)\end{array}$ & $\begin{array}{c}1.879 \\
(1.565)\end{array}$ & $\begin{array}{c}2.547 \\
(1.674)\end{array}$ & $\begin{array}{c}2.026 \\
(1.834)\end{array}$ & $\begin{array}{c}2.464 \\
(1.776)\end{array}$ \\
\hline Career Articles & $\begin{array}{c}24.210 \\
(39.450)\end{array}$ & $\begin{array}{c}28.325^{\mathrm{a}} \\
(42.395)\end{array}$ & $\begin{array}{c}11.909 \\
(22.597)\end{array}$ & $\begin{array}{c}33 \cdot 311 \\
(45 \cdot 324)\end{array}$ & $\begin{array}{c}14.192 \\
(24.584)\end{array}$ & $\begin{array}{c}15.025 \\
(26.164)\end{array}$ & $\begin{array}{r}8.731 \\
(17.955\end{array}$ \\
\hline Institutional Income & $\begin{array}{c}83.333 \\
(48.442)\end{array}$ & $\begin{array}{l}88.932^{\mathrm{a}} \\
(51.090)\end{array}$ & $\begin{array}{c}66.595 \\
(31.712)\end{array}$ & $\begin{array}{c}93.702 \\
(51.934)\end{array}$ & $\begin{array}{c}69.583 \\
(31.454)\end{array}$ & $\begin{array}{c}76.206 \\
(45.039)\end{array}$ & $\begin{array}{c}62.437 \\
(31.352)\end{array}$ \\
\hline $\mathrm{N}$ & 9,350 & 6,860 & 2,490 & 4,810 & $1,350 \quad 2$ & 2,050 & 1,150 \\
\hline
\end{tabular}

Note: Income is thousands of dollars. Standard deviation of continuous variables in parenthesis; $\mathrm{p}$-values for t-test that mean of traditional and mature are equal.
a. $p<0.01$
b. $p<0.05$
c. $p<0.1$ in the full sample.

Mature faculty have less experience reflecting the later start on their careers, and females have less experience than males. About ninety percent of the sample have the title of professor, about five percent have the title of lecturer/instructor, and about three-fourths have tenure or are in a tenure-track position. Mature faculty teach more than traditional faculty and they publish substantially fewer articles 
in refereed journals. ${ }^{7}$ Females teach about the same number of classes as males but have published fewer refereed articles.

Income is a primary variable of interest and the variable reported is total institutional income. The average faculty member has a total institutional income of $\$ 88,333 .{ }^{8}$ Mature faculty earn over $\$ 20,000$ less than traditional faculty, and the difference is larger for males than for females. As with differences in publications, it is possible some of these differences reflect difference in experience or field-of-study. For example, the mean salary for those in education is $\$ 68,000$, whereas the mean salary for those in biological sciences is $\$ 85$, 000. As shown next, there are age and sex differences in fields-of study.

Table 2 provides a breakdown of fields-of-study (FOS). Each column sums to 100 percent. Social sciences, physical sciences, health sciences, and biological sciences are the four largest fields accounting for over half of the sample. These four fields account for almost 50 percent of traditional males and almost 60 percent of traditional females, whereas they only account for about a third of mature faculty of either gender. Mature male faculty are not as heavily represented in health sciences, but instead are more heavily in business. Sixty percent of mature females are found in English, social sciences, health sciences and education. In general, there is substantial fieldsegregation by age and gender.

\section{Transition from graduate school to employer}

The starting point of a career is incredibly important in any job, and perhaps more so in academics than others. The real starting point of an academic career, however, is the institution from which faculty obtain their terminal degree. To visualize where future faculty start and the transition to employment, schools from which degrees are obtained are divided into Research I (R-I), Research II (R-II) and Doctoral

7 Differences in number of classes taught might reflect differences in institution of employment. Faculty at R/D institutions teach 1.55 classes per semester and faculty at all other institutions teach 2.75 classes per semester, a statistically significant difference ( $\mathrm{p}$-value $=0.00)$.

8 NSOPF provides several measures of income. Traditional faculty have a base institutional income that is also about $\$ 21$,ooo larger than mature faculty. Total household income is $\$ 24$, ooo different for the two groups. 
Table 2 Field of study.

\begin{tabular}{|c|c|c|c|c|c|c|c|}
\hline \multirow{2}{*}{ Variable } & \multicolumn{3}{|c|}{ Full Sample } & \multicolumn{2}{|c|}{ Male } & \multicolumn{2}{|c|}{ Female } \\
\hline & All & Trad. & Mature & Trad. & Mature & Trad. & Mature \\
\hline Business & 0.064 & $0.052^{a}$ & 0.101 & 0.056 & 0.124 & 0.041 & 0.068 \\
\hline Arts & 0.031 & $0.026^{a}$ & 0.045 & 0.022 & 0.042 & 0.036 & 0.050 \\
\hline Biological Sciences & 0.136 & $0.159^{a}$ & 0.068 & 0.158 & 0.091 & 0.160 & 0.037 \\
\hline Communication & 0.018 & $0.015^{a}$ & 0.028 & 0.011 & 0.031 & 0.026 & 0.024 \\
\hline Computer & 0.028 & 0.027 & 0.031 & 0.033 & 0.040 & 0.014 & 0.019 \\
\hline Education & 0.068 & $0.037^{a}$ & 0.162 & 0.028 & 0.109 & 0.062 & 0.237 \\
\hline Engineering & 0.066 & $0.071^{a}$ & 0.052 & 0.091 & 0.076 & 0.018 & 0.018 \\
\hline English & 0.050 & \multicolumn{2}{|c|}{$0.046^{\mathrm{b}} 0.061$} & 0.035 & 0.046 & 0.077 & 0.082 \\
\hline Language & 0.036 & $0.030^{a}$ & 0.055 & 0.022 & 0.053 & 0.049 & 0.058 \\
\hline Heath Sciences & 0.161 & $0.180^{a}$ & 0.106 & 0.167 & 0.061 & 0.214 & 0.168 \\
\hline Math & 0.049 & $0.055^{a}$ & 0.031 & 0.065 & 0.038 & 0.028 & 0.021 \\
\hline Philosophy & 0.032 & $0.030^{b}$ & 0.041 & 0.035 & 0.050 & 0.015 & 0.028 \\
\hline Physical Sciences & 0.084 & $0.099^{a}$ & 0.040 & 0.113 & 0.058 & 0.061 & 0.016 \\
\hline Psychology & 0.052 & $0.056^{a}$ & 0.041 & 0.046 & 0.024 & 0.083 & 0.063 \\
\hline Social Sciences & 0.121 & $0.116^{b}$ & 0.137 & 0.116 & 0.157 & 0.116 & 0.110 \\
\hline
\end{tabular}

Note: $p$-values for t-test that mean of traditional and mature are equal.
a. $p<0.01$
b. $\mathrm{p}<0.05$
c. $p<0.1$ in the full sample

I and II (D-I/II). A similar classification is done for employers, but for employers Research II is grouped with the doctoral institutions. To focus on the transition from graduate school to employment, the sample is restricted to new faculty. Table $\mathbf{3}$ identifies the Carnegie classification of the degree granting institution and the employer.

Two-thirds of the sample obtain their degree from a Carnegie Research I institution, but mature faculty are thirteen percentage points less likely than traditional faculty to obtain their degree from an R-I institution. This holds for males and females. Mature faculty of either sex are more likely to have attended Research II designated schools or Doctoral I and II institutions (D-I\&II). Although sixty-four percent of the sample attended an R-I, only thirty-two percent obtain employment at an R-I. Mature faculty are less likely to obtain employment at an R-I and they are more likely to find employment at an Other classified school. Whether mature or traditional, there are no gender differences in the likelihood of attending an R-I program, but traditional females are less likely than traditional males to obtain employment at an R-I. 
Table 3 Graduate and employer Carnegie classification - new faculty.

\begin{tabular}{|c|c|c|c|c|c|}
\hline \multirow[t]{2}{*}{ Variable } & \multicolumn{3}{|c|}{ Full } & Male & \multirow[b]{2}{*}{ Trad. Mature } \\
\hline & All & Trad. $\mathrm{N}$ & Mature & Trad. Mature & \\
\hline \multicolumn{6}{|l|}{ Degree from } \\
\hline Research I & 0.637 & $0.687^{a}$ & a 0.557 & 0.6820 .549 & 0.6940 .565 \\
\hline Research II & 0.111 & $0.081^{a}$ & 0.158 & 0.0860 .158 & 0.0730 .159 \\
\hline Doctoral I/II & 0.121 & $0.099^{b}$ & b 0.155 & $\begin{array}{lll}0.097 & 0.139\end{array}$ & 0.1020 .170 \\
\hline Other & 0.132 & 0.134 & 0.130 & $0.136 \quad 0.154$ & 0.1310 .106 \\
\hline \multicolumn{6}{|l|}{ Employer is } \\
\hline Research I & 0.324 & $0.386^{\mathrm{a}}$ & 0.227 & 0.4220 .256 & 0.3330 .198 \\
\hline Research II/Doctoral I/Doctoral II & 0.210 & 0.205 & 0.219 & 0.2010 .179 & 0.2110 .258 \\
\hline Other & 0.465 & $0.410^{a}$ & 0.554 & $0.377 \quad 0.565$ & 0.4560 .544 \\
\hline
\end{tabular}

Note: $p$-values for $\mathrm{t}$-test that mean of traditional and mature are equal.

a. $p<0.01$

b. $p<0.05$

c. $\mathrm{p}<0.1$ in the full sample

Older faculty are less likely to attend R-I institutions, but this does not mean that older faculty attending R-I institutions are less likely to obtain employment at such institutions. Table 4 has two panels, Panel A is for males and Panel B is for females. For each age-gender group, graduate school is divided into R-I institutions and all others (Not R-I). Each row sums to one. For example, 31.40 percent of mature males attending an R-I find employment at an R-I, 21.19 percent find employment at a R-II, D-I, or D-II, and 47.41 percent find employment at an Other classified school. By comparison, traditional male faculty are seventeen percentage points more likely to attend an R-I and find employment at an R-I. Almost thirty percent of traditional male faculty that obtain a degree from a not R-I find employment at an R-I versus only 18.47 percent of mature males. Thus, mature males are much more likely to obtain employment at a lower classified research institution independent of the Carnegie classification of their graduate institution.

The differences between traditional and mature faculty is not as large for females. Mature females attending R-I graduate programs are only 7 percentage points less likely to work at an R-I than are traditional females that attended an R-I (30.66 percent versus 37.35 percent). Most striking is that twenty-four percent of traditional females not attending an R-I graduate program obtained employment at an R-I compared with less than six percent of mature females. This translates 
Table 4 Cross-tabulation of graduate and employer institution - new faculty.

\begin{tabular}{|c|c|c|c|c|c|}
\hline \multicolumn{3}{|l|}{ Employer is } & R-I & R-II/D-I\&II & Other \\
\hline \multicolumn{6}{|c|}{ Panel A: Male } \\
\hline \multirow[t]{4}{*}{ Male } & Mature & Degree from R-I & 0.3140 & 0.2119 & 0.4741 \\
\hline & & Degree not R-I & 0.1847 & 0.1399 & 0.6754 \\
\hline & Traditional & Degree from R-I & 0.4819 & 0.2158 & 0.3023 \\
\hline & & Degree not R-I & 0.2939 & 0.1683 & 0.5378 \\
\hline \multicolumn{6}{|c|}{ Panel B: Female } \\
\hline \multirow[t]{4}{*}{ Female } & Mature & Degree from R-I & 0.3066 & 0.2342 & 0.4592 \\
\hline & & Degree not R-I & 0.0574 & 0.2892 & 0.6534 \\
\hline & Traditional & Degree from R-I & 0.3735 & 0.2020 & 0.4245 \\
\hline & & Degree not R-I & 0.2416 & 0.2302 & 0.5282 \\
\hline
\end{tabular}

into differences in employment at Other institutions. In general, the age seems to have a bigger influence on the path from graduate program to employer for males than for females.

\section{Multivariate analysis of full sample}

The previous analysis makes clear that older students are less likely to attend R-I graduate programs and less likely to obtain R-I employment. The next question is whether this translates into differences in income. The full sample is analyzed using ordinary least squares so as to control for factors such as experience and field-of study. Table 5 shows the coefficients from OLS regressions with total institutional income, in thousands of dollars, as the dependent variable. ${ }^{9}$ Regressions are estimated separately for males and females. Age Highest Degree and its square are the primary variables of interest in each regression. All regressions include experience and its square, race, marital status, country of birth and FOS as control variables. The third and fourth columns also include Employer Is R/D. If older hires are treated differently because of anticipated differences in research potential, then it is important to differentiate those employed at institutions with more of a research expectation. Ideally, type of employer and income would be modeled simultaneously. Efforts to model an endogenous switching

9 Regressions were also estimated after taking the log of continuous variables. The $\mathrm{R}^{2}$ was higher with data in the levels, so those estimates are reported here. 
Table 5 OLS of total institution income.

\begin{tabular}{lllll} 
& Male & Female & Male & \multicolumn{2}{l}{ Female } \\
\hline Age Highest Degree & $-6.6567^{\mathrm{a}}$ & $-3.4037^{\mathrm{a}}$ & $-6.0515^{\mathrm{a}}$ & $-3.4708^{\mathrm{a}}$ \\
& $(7.80)$ & $(3.78)$ & $(7.24)$ & $(3.86)$ \\
Age Highest Degree $^{2}$ & $0.0750^{\mathrm{a}}$ & $0.0364^{\mathrm{a}}$ & $0.070 \mathrm{a}^{\mathrm{a}}$ & $0.038 \mathrm{o}^{\mathrm{a}}$ \\
& $(6.62)$ & $(3.21)$ & $(6.33)$ & $(3.35)$ \\
Experience & $2.3511^{\mathrm{a}}$ & $1.8246^{\mathrm{a}}$ & $2.4050^{\mathrm{a}}$ & $1.8233^{\mathrm{a}}$ \\
& $(11.23)$ & $(6.25)$ & $(11.72)$ & $(6.19)$ \\
Experience & $-0.0358^{\mathrm{a}}$ & $-0.0197^{\mathrm{c}}$ & $-0.0371^{\mathrm{a}}$ & $-0.0196^{\mathrm{c}}$ \\
& $(6.32)$ & $(1.91)$ & $(6.68)$ & $(1.89)$ \\
Employer is R/D & & & $13.4629^{\mathrm{a}}$ & $7.2022^{\mathrm{a}}$ \\
& & & $(11.34)$ & $(5.17)$ \\
R-squared & 0.2858 & 0.2904 & 0.3040 & 0.2995 \\
\hline
\end{tabular}

Note: Regressions for males have 6,160 observations and regressions for females have 3,190. Regressions include controls for race/ethnicity, marital status, whether born in the U.S., and FOS; t-statistics in parentheses.
a. $p<0.01$
b. $\mathrm{p}<0.05$
c. $p<0.1$

regression model were unsuccessful because an appropriate instrument could not be found to identify the equations.

A male obtaining a degree at 45 earns $\$ 15,500$ less than a similar 30 year-old. The age penalty for females is about $\$ 10,100$. This is a 17.5 percent penalty relative to the mean income for males $(\$ 88,600)$, and the penalty for females is 14 percent of mean income for females $(\$ 71,539)$. In the next two columns, a dummy variable that equals one if the employing institution is classified as research or doctoral is added. The coefficients are large and statistically significant. Males earn over $\$ 13,000$ more at research/doctoral institutions and females earn \$7,200 more. The coefficients on Age Highest Degree are not altered by the inclusion of the Carnegie classification variable.

The previous estimates do not account for the fact that some faculty, even at research institutions, are in positions that do not require research. To the extent that differences in earnings by age reflect differences in actual or expected research productivity, the age penalty will be larger for those in positions requiring research. Instead of including more control variables and interaction terms, Table 6 reports eight sets of regressions that divide the sample first by whether the person has the title of professor. The sample is further divided 
Table 6 Professorial status and type of institution.

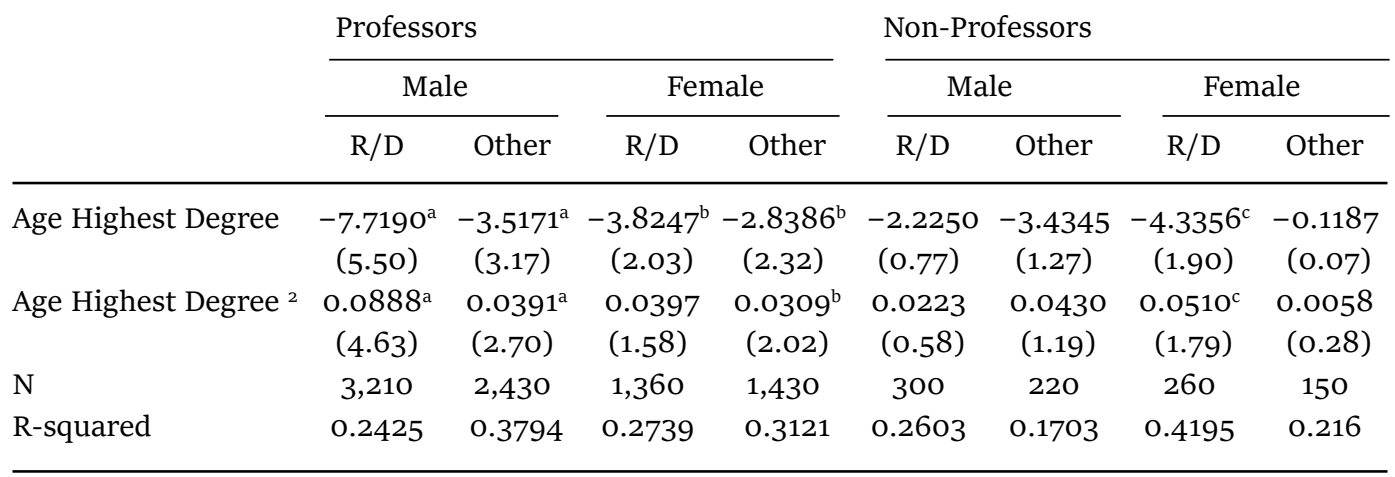

Note: Regressions also include Experience, Experience ${ }^{2}$, Asian, Black, Other Race, Single, Born US, and controls for FOS; t-statistics in parentheses.
a. $p<0.01$
b. $p<0.05$
c. $p<0.1$

The F-Test is a test that the marginal effect of Age Highest Degree is equal across the two regressions.

between institutions classified as research/doctoral and all others and then further divided by male and female.

For professors (the first four columns), age at time of degree impacts income in the same manner found in Table 5. If research expectations are a driving force for the results, then the age-penalty will be larger at R/D institutions. The quadratic term makes the comparison across R/D and Other institutions more difficult because the marginal effect varies with age. An F-test was calculated every five years from age 25 to 50 . The marginal effect for male professors at $\mathrm{R} / \mathrm{D}$ institutions is statistically different from male professors at other institutions at age twenty-five, thirty, and thirty-five, but the difference is not statistically different at ages forty, forty-five, and fifty. ${ }^{10}$ This result does not mean that the age penalty disappears at age 40, but that the penalty does not increase beyond this age. For example, a male professor at an R/D institution that was fortyyears-old when getting their degree earns $\$ 15$, ooo less than a similar thirty-years-old at the time of degree. The age penalty for male professors at other institutions is about half that of male professors at $\mathrm{R} / \mathrm{D}$ institutions. 
Female professors that are older upon earning their degree also earn less. Repeating the calculation done for males, the forty-year-old female professor at an R/D earns $\$ 10,500$ less than a similar thirty year old. The age penalty at Other institutions is about two-thirds this size. The penalty for female professors at R/D institutions is similar in magnitude to male professors at Other institutions.

The estimates are very different for those in a position with a title other than professor. The marginal effect of age at time of degree is statistically insignificant for male, non-professors, regardless of type of institution. The income of female, non- professors at Other institutions is statistically unrelated to age at time of degree. Female, nonprofessors at R/D institutions do appear to face an age penalty. It should be noted that the non-professor sample is much smaller than the professor sample.

\section{Income of new faculty}

Analysis of the full sample provides evidence of a negative relation between age at time of degree and income. While the data does not make it possible to identify the mechanism generating the different outcomes, it is possible to determine if the penalty exists at the beginning of the academic career. Initial salary and placement will be based largely on expectations of future productivity. Given that mature and traditional faculty are both beginning careers, it is possible to hold experience constant and focus on the role of age at time of degree on income. Thus, the following analysis restricts the sample to those within three years of leaving graduate school.

Table 7 is similar to the regressions reported in Table 5 with a few changes. There is no quadratic in Age Highest Degree because both terms of the quadratic are statistically insignificant. ${ }^{11}$ Experience is not included because it is not a statistically significant predictor, likely due to the much smaller variation in experience for these new faculty. The estimates suggest that mature faculty earn less from the beginning of their careers, and the age penalty is larger for males than for females, although the difference is not statistically significant ( $\mathrm{p}$-value 
Table 7 OLS of total institution income - new faculty.

\begin{tabular}{lcccc} 
& Male & Female & Male & Female \\
\hline Age Highest Degree & $-0.4690^{\mathrm{b}}$ & $-0.3602^{\mathrm{a}}$ & $-0.3649^{\mathrm{c}}$ & $-0.3440^{\mathrm{a}}$ \\
& $(2.48)$ & $(3.40)$ & $(1.93)$ & $(3.26)$ \\
Employer is R/D & & & $7.5164^{\mathrm{a}}$ & 2.0813 \\
& & & $(2.91)$ & $(1.25)$ \\
R-squared & 0.339 & 0.308 & 0.351 & 0.310 \\
\hline
\end{tabular}

Note: Regressions for males have 560 observations and regressions for females have 530 . Regressions include controls for FOS; t-statistics in parentheses.

a. $p<0.01$

b. $p<0.05$

c. $p<0.1$

F-Test (1) tests that the coefficient on Age Highest Degree is equal across the male and female regressions; F-Test (2) tests if Age Highest Degree plus Age Degree $*$ Employer are equal for males and females.

$=0.62$ ). The inclusion of a dummy variable for Employer Is R/D suggests males hired to R/D institutions earn $\$ 7,500$ more, but there is no statistical relation between institution type and income for new female faculty. The inclusion of the control variable lowers the coefficient on age at time of degree for males so that it is almost identical as that for females. The estimates in the last two columns implies a fifteen year age penalty that is between $\$ 5,000$ and $\$ 5,500$, suggesting that much of the age penalty is realized at the point of hire.

Table 8 is similar to Table 4 except that the non-professor sample is small so it is not possible to separate R/D from Other institutions. The results suggest that new, male professors at R/D institutions face an age penalty three-times larger than male professors at Other institutions ( $\mathrm{p}$-value-o.08). A 45 year-old male professor at a $\mathrm{R} / \mathrm{D}$ institution earns $\$ 19,600$ less than a 30 year-old at a R/D institution whereas the difference at Other institutions is about $\$ 6,280$ less. Female professors earn between $\$ 5,400$ and $\$ 8,400$ less for every 15 years older they are at the time to degree but the difference between female professors at R/D and Other institutions is not statistically significant ( $\mathrm{p}$-value $=0.39$ ).

The results for non-professors are somewhat unexpected. Income is positively related to age at time of degree for male non-professors, and the coefficient is large. Income for female non-professors is unrelated to age at time of degree, although the difference between male and female professors is not statistically significant ( $p$-value $=0.26$ ). It is worth noting, that sample sizes for non-professors are small. 
Table 8 By professorial status and type of institution - new faculty.

\begin{tabular}{|c|c|c|c|c|c|c|}
\hline & \multicolumn{4}{|c|}{ Professors } & \multicolumn{2}{|c|}{ Non-Professors } \\
\hline & \multicolumn{2}{|l|}{ Male } & \multicolumn{2}{|l|}{ Female } & \multirow[t]{2}{*}{ Male } & \multirow[t]{2}{*}{ Female } \\
\hline & $\mathrm{R} / \mathrm{D}$ & Other & $\mathrm{R} / \mathrm{D}$ & Other & & \\
\hline Age Highest Degree & $\begin{array}{c}-1.3085^{\mathrm{a}} \\
(2.96)\end{array}$ & $\begin{array}{c}-0.4191^{\mathrm{c}} \\
(1.79)\end{array}$ & $\begin{array}{c}-0.5587^{\mathrm{a}} \\
(2.86)\end{array}$ & $\begin{array}{c}-0.3599^{a} \\
(2.81)\end{array}$ & $\begin{array}{c}0.6354^{\mathrm{c}} \\
(1.75)\end{array}$ & $\begin{array}{c}-0.0398 \\
(0.17)\end{array}$ \\
\hline Employer is R/D & & & & & $\begin{array}{c}11.9469^{c} \\
(1.88)\end{array}$ & $\begin{array}{c}-8.7740^{\mathrm{c}} \\
(1.83)\end{array}$ \\
\hline $\mathrm{N}$ & 200 & 250 & 190 & 230 & 120 & 110 \\
\hline R-squared & 0.492 & 0.435 & 0.386 & 0.293 & 0.291 & 0.290 \\
\hline
\end{tabular}

Note: Regressions also include Asian, Black, Other Race, Single, Born US, and controls for FOS; t-statistics in parentheses.
a. $p<0.01$
b. $p<0.05$
c. $p<0.1$
F-Test (1) tests that the coefficient on Age Highest Degree are equal across R/D and Other.

\section{Conclusions}

The estimates suggest that age upon obtaining a Ph.D. is related to labor market outcomes. The data also reveal that the patterns are different for males and females. For males under thirty five year of age, forty-eight percent of those attending a graduate program housed in a Carnegie Research I institution also obtained employment at a Research I institution. For males over thirty-five, this drops to thirtyone percent. The difference for females exists, but it is much smaller.

It is not surprising that these differences in pattern in graduate school attendance and employment manifest in differences income. A male obtaining their degree at forty-five earns $\$ 15,500$ less than a similar thirty-year-old. For females, this penalty is about $\$ 10,100$. A deeper look into the data shows that the differences are driven by those with the title of professors at research and doctoral institutions. For males, the calculated age penalty is about twice as large at research/doctoral schools relative to other institutions. The penalty for females is smaller but still not trivial. Lastly, a substantial age penalty exists for faculty in the first three year after obtaining their degree suggesting that differences in income cannot be completely attributed to differences in realized productivity. 
Acknowledgments - The author acknowledges the helpful comments of Dan Hamermesh. All remaining errors are the author's.

Supplementary materials associated with this article are not available; the authors do not have permission to share data.

\section{References}

Carlsson, Magnus, Eriksson, Stefan, 2019. Age discrimination in hiring decisions: evidence from a field experiment in the labor market. Labour Econ 59, 173-183.

Farber, Henry S., Silverman, Dan, Wachter, Till M. Von, 2017. Factors determining callbacks to job applications by the unemployed: An audit study. RSF Russell Sage Found. J. Soc. Sci. 3 (no. 3), 168-201.

Krause, Annabelle, Rinne, Ulf, Zimmermann, Klaus F., 2012. Anonymous job applications of fresh Ph. D. economists. Econ. Lett. 117 (no. 2), 441-444

Monks, James, Robinson, Michael, 2000. Gender and racial earnings differentials in academic labor markets. Econ. Inq. 38 (no. 4), 662-671.

Neumark, David, Burn, Ian, Button, Patrick, 2019. Is it harder for older workers to find jobs? New and improved evidence from a field experiment. J. Polit. Econ. 127 (no. 2), 922-970.

Oster, Sharon M., Hamermesh, Daniel S., 1998. Aging and productivity among economists. Rev. Econ. Stat. 80 (no. 1), 154-156.

Rutledge, Matthew S., Sass, Steven A., Ramos-Mercado, Jorge D., 2017. How does occupational access for older workers differ by education? J. Labor Res. 38 (no. 3), 283-305.

Stock, Wendy A., Siegfried, John J., 2015. The undergraduate origins of PhD economists revisited. J. Econ. Educ. 46 (no. 2), 150-165.

Warman, Casey, Worswick, Christopher, 2010. Mandatory retirement rules and the retirement decisions of university professors in Canada. Labour Econ. 17 (no. 6), 1022-1029. 